\title{
Penerapan Blended Librarian di Era Digital (Studi Kasus di Perpustakaan Universitas Muhammadiyah Yogyakarta)
}

\author{
Aidilla Qurotianti ${ }^{*}$ \\ ${ }^{1}$ Universitas Muhammadiyah Yogyakarta \\ "Korespondensi: aidillaqurotianti93@gmail.com
}

\begin{abstract}
The digital era provides a challenge for librarians, especially for academic librarians in the university library. For the sake of the Tri Dharma Perguruan Tinggi in a university, the university library needs to provide services following the pattern of information needs of the academic community. In addition to improving services and facilities, the library must also enhance the ability and expertise of human resources they have, namely librarians. Not only able to process library materials, but academic librarians must also be able to combine with competencies in the field of information technology and have a role in the process of improving student learning. The capability in combining these three combinations is called a blended librarian. One of the university libraries that has librarians who have implemented blended librarians is the Universitas Muhammadiyah Yogyakarta Library. This research aims to explore the implementation of blended librarians in the digital era at Universitas Muhammadiyah Yogyakarta Library. This research employs a qualitative descriptive study using the case study method. The results shows that blended librarian in the Universitas Muhammadiyah Yogyakarta were implemented by conducting some roles, which includes providing and managing resources, providing a facility to supports learning commons, optimizing ICT for information access, acting as as a liaison to another source in outside university, conducting user education, providing information literacy, assisting plagiarism prevention program, references manager training, and assisting research.
\end{abstract}

Keywords: blended librarian; collage library; tri dharma perguruan tinggi; digital era

\begin{abstract}
Abstrak
Era digital merupakan tantangan bagi pustakawan, terutama pustakawan akademik di perpustakaan universitas. Demi menjunjung Tri Dharma Perguruan Tinggi di universitas, perpustakaan perguruan tinggi harus menyediakan layanan yang mengikuti pola kebutuhan informasi dari kalangan akademik. Selain meningkatkan layanan dan fasilitas, perpustakaan juga harus meningkatkan kemampuan dan keahlian sumber daya manusia di sana, yaitu pustakawan. Tidak hanya mampu mengolah bahan pustaka, tetapi pustakawan akademik juga harus memiliki kompetensi di bidang teknologi informasi dan memiliki peran dalam proses peningkatan pembelajaran mahasiswa. Kemampuan dalam menggabungkan ketiga kombinasi ini disebut blended librarian. Salah satu perpustakaan perguruan tinggi yang telah memiliki pustakawan dengan kemampuan blended librarian yaitu Perpustakaan Universitas Muhammadiyah Yogyakarta. Berdasarkan pemaparan tersebut, peneliti tertarik pada penelitian tentang implementasi blended librarian di era digital di Perpustakaan Universitas Muhammadiyah Yogyakarta. Penelitian ini adalah penelitian deskriptif kualitatif dengan menggunakan metode studi kasus. Hasil dari penelitian ini adalah implementasi blended librarian di Universitas Muhammadiyah Yogyakarta adalah 1) Menyediakan dan mengelola sumber referensi; 2) Menyediakan fasilitas yang mendukung learning commons; 3) Mengoptimalkan TIK untuk akses informasi; 4) Sebagai penghubung ke sumber lain di luar universitas; 5) User Education; 6) Literasi Informasi; 7) Pencegahan Plagiarisme; 8) Pelatihan Manajer Referensi; dan 9) Pendamping Dosen.
\end{abstract}

Kata Kunci: blended librarian; perpustakaan perguruan tinggi; tri dharma perguruan tinggi; era digital

\section{PENDAHULUAN}

Era digital adalah tantangan bagi pustakawan, terutama pustakawan akademik di perpustakaan universitas. Akses informasi yang mudah didapatkan melalui internet membuat beberapa mahasiswa menjadikan perpustakaan sebagai alternatif kedua. Mahasiswa merupakan net generation, di mana mereka adalah generasi yang tumbuh dalam dominasi penggunaan teknologi informasi sehingga mereka memiliki pola pencarian informasi yang berbeda dari generasi sebelumnya. Fenomena ini menjadikan media internet sebagai andalan bagi mereka yang ingin mencari informasi dengan cepat dan praktis. 
Beberapa faktor menjadikan mahasiswa menggunakan internet sebagai media yang sering digunakan sebagai gerbang informasi. Kemudahan penggunaan dan kecepatan akses adalah faktor utama dalam mendapatkan informasi dan pengetahuan yang mereka butuhkan. Hal ini merupakan tantangan bagi perpustakaan perguruan tinggi di era digital yang semakin kompleks. Tidak lagi bersaing dengan institusi lain, tetapi bersaing dengan kemudahan internet di era serba digital. Hal tersebut memberikan dampak perubahan yang cukup besar di lingkungan perputakaan, khususnya perubahan kebutuhan dan perilaku pencarian informasi. Perubahan perilaku pencarian informasi dan kebutuhan terhadap perpustakaan membuat pustakawan dituntut untuk dapat terus mengikuti perkembangan terkini dalam mengelola perpustakaan, termasuk perpustakaan perguruan tinggi (Yusuf, 2015).

Demi menjunjung asas Tri Dharma Perguruan Tinggi di universitas, perpustakaan perguruan tinggi harus menyediakan layanan yang mengikuti pola kebutuhan informasi dari civitas akademik, terutama mahasiswa yang berbasis pada teknologi informasi. Sesuai dengan Undang-Undang Republik Indonesia Nomor 43 Tahun 2007, Pasal 24 ayat 3 menjelaskan bahwa: "Perpustakaan pendidikan tinggi mengembangkan layanan perpustakaan berdasarkan teknologi informasi dan komunikasi.". Dari penjelasan tersebut, diketahui bahwa perpustakaan perguruan tinggi harus menyesuaikan kebutuhan layanan dengan perkembangan teknologi informasi sehingga perpustakaan perguruan tinggi masih dapat mempertahankan kredibilitasnya sebagai pusat informasi bagi civitas akademik.

Selain meningkatkan layanan dan fasilitas, perpustakaan juga harus meningkatkan kemampuan dan keahlian sumber daya manusia, yaitu pustakawan. Pustakawan adalah komponen utama dalam menggerakkan dan mengelola kemajuan perpustakaan, terutama di era digital saat ini. Menurut Putri (2019) selama beberapa tahun terakhir, di Indonesia sudah semakin banyak pustakawan yang sudah mendapatkan pelatihan formal dalam desain instruksional dan teknologi bagaimana menjadi lebih mahir dengan desain produk instruksional yang dapat menaikkan tingkatannya dalam keterlibatan di proses belajar mengajar. Secara khusus, keterampilan diri oleh pustakawan yang harus di-eksplore yaitu membuat koneksi dan jaringan organisasi yang lebih baik, dan hubungan kolaboratif dengan fakultas.

Sebagai pustakawan akademik di perpustakaan perguruan tinggi, mereka dituntut untuk dapat memberikan kompetensi dan peran untuk dapat mempertahankan fungsi perpustakaan perguruan tinggi sebagai pusat informasi, pengetahuan, dan penelitian. Tentunya hal ini membutuhkan pustakawan yang berkualitas tinggi yang memiliki keinginan kuat untuk mengetahui dan belajar tentang bidang ilmu lain yang menjadi core (inti) bidang perpustakaan yang menjadi tanggung jawabnya (Istiana, 2017). Tingkat kompetitif yang tinggi di antara perguruan tinggi, baik pada tingkat lokal, nasional, regional, dan internasional telah memicu perguruan-perguruan tinggi di dunia untuk selalu meningkatkan kualitas system penyelenggaraan pendidikan (Andayani, 2018). Berbagai peningkatan dilakukan oleh pustakawan akademik di perguruan tinggi, mulai dari meningkatkan pelayanan, fasilitas serta memperbanyak dan mengolah koleksi bahan pustaka.

Tidak hanya mengolah bahan pustaka, tetapi pustakawan akademik juga harus mampu memadukan dengan kompetensi di bidang teknologi informasi dan memiliki peran dalam proses peningkatan pembelajaran mahasiswa. Perkembangan teknologi informasi tersebut membuat pustakawan harus mampu memperluas wawasannya dan memiliki pengetahuan yang cukup mengenai web sites yang akademis, serta mampu mengorganisasikan sumber-sumber di internet sehingga mahasiswa dan dosen dapat menemukan informasi berkualitas tinggi yang berkaitan dengan subjek yang mereka teliti (Almah, 2014). Kemampuan dalam menggabungkan ketiga kombinasi ini disebut blended librarian. Blended librarian adalah pustakawan akademik yang menggabungkan keahlian tradisional kepustakawanan dengan keterampilan perangkat keras 
maupun perangkat lunak teknologi informasi, serta kemampuan sebagai perancang pengajaran atau pendidikan untuk menerapkan teknologi secara tepat dalam proses belajar-mengajar (Bell, Steven J., 2004).

Tidak hanya memiliki hard skill, pustakawan juga harus memiliki soft skill. Arti penting penguasaan soft skill bagi pustakawan adalah untuk meningkatkan intuisi, kepekaan, dan kepekaan ketika bekerja (Fatmawati, 2010). Maka dari itu pustakawan yang mempunyai soft skill akan selangkah lebih maju, dan harapan menjadi pustakawan professional kian mendekati kenyataan. Blended librarian memiliki tugas penting yaitu menyediakan informasi tercetak dan digital dengan pengelolaan konten yang siap disajikan untuk pemustaka (Vargas et al., 2015). Dalam upaya memenuhi kebutuhan informasi pemustaka tersebut maka pustakawan harus melakukan; (a) Perencanaan dan identifikasi kebutuhan informasi pemustaka: sumber daya informasi (tercetak dan digital), pelatihan untuk pengelola perpustakaan, dan bimbingan kepada pemustaka. (b) Pemenuhan kebutuhan informasi yang tepat dari sumber yang benar untuk pemustaka, melakukan promosi dan literasi informasi (c) Melakukan integrasi melalui jaringan media sosial, aplikasi dan situs web institusi. (d) Bimbingan dan konsultasi rujuan online.

Kompetensi blended librarian tersebut sangat diperlukan di lingkungan perguruan tinggi, sehingga pustakawan harus ikut berperan aktif dalam setiap perubahan lingkungan di perguruan tinggi. Selain itu pustakawan juga harus ikut mengembangkan dan mengimplementasikan berbagai program perguruan tinggi yang dapat meningkatkan produksi ilmu pengetahuan dan teknologi informasi. Peran pustakawan akademik sebagai "blended librarian" adalah adanya perubahan system penyelenggaraan pendidikan yang didasarkan atas pemanfaatan produk-produk dan inovasi teknologi untuk keperluan pembelajaran (de Lima et al., 2017). Hal tersebut membuat perguruan tinggi melirik pustakawan akademik untuk melibatkan mereka dalam pelaksanaan kegiatan pembelajaran dan kegiatan akademik lainnya.

Pustakawan tidak hanya menjadi "sistem pendukung," tetapi juga menjadi "kolaborator akademik" dalam berbagai kegiatan ilmiah universitas (Andayani, 2018). Salah satu perpustakaan perguruan tinggi yang memiliki pustakawan yang telah menerapkan blended librarian adalah Perpustakaan Universitas Muhammadiyah Yogyakarta. Selain dapat mengelola bahan pustaka secara manual atau berbasis teknologi informasi, blended librarian di perpustakaan UMY juga memiliki peran dan berpartisipasi dalam pengembangan pembelajaran bagi mahasiswa. Peran blended librarian yang telah diterapkan di perpustakaan UMY dibagi menjadi tiga bagian, yaitu manager, mediator, dan instruktur.

Berdasarkan uraian masalah di atas, peneliti tertarik meneliti bagaimana implementasi blended librarian di era digital di Perpustakaan UMY. Melalui tulisan ini, diharapkan dapat menggambarkan peran blended librarian dalam memenuhi kebutuhan informasi siswa di era digital di Perpustakaan UMY

\section{METODE PENELITIAN}

Penelitian ini adalah penelitian kualitatif dengan menggunakan metode studi kasus. Studi kasus adalah studi mendalam tentang suatu peristiwa, lingkungan, dan situasi tertentu dalam mengekspresikan atau memahami sesuatu (Sulistyo-Basuki, 2006). Penelitian ini menggunakan metode studi kasus karena peneliti mengkaji suatu hal yang terdapat pada kasus tertentu, yaitu blended librarian di Perpustakaan Universitas Muhammadiyah Yogyakarta. Tujuan penggunaan penelitian studi kasus adalah untuk menjelaskan bagaimana keberadaan dan mengapa kasus tersebut terjadi (Yin, 2011). Penelitian studi kasus bukan hanya menjawab pertanyaan penelitian tentang 'apa' (what) obyek yang diteliti, tetapi lebih menyeluruh dan komprehensif lagi adalah tentang 'bagaimana' (how) dan 'mengapa' (why). 
Peneliti melakukan wawancara terstruktur kepada para informan. Peneliti dengan menggunakan sampel purposive sampling, di mana informan dipilih berdasarkan tujuan / tujuan tertentu. Informan yang ditentukan oleh peneliti berjumlah satu dosen (RA) dan lima pustakawan (NDF, LN, APW, EK, MEC) dimana mereka merupakan pustakawan yang memiliki kriteria telah bekerja selama lebih dari tiga tahun. Peneliti juga melakukan observasi secara langsung dengan terlibat dalam kegiatan sehari-hari orang atau situasi yang diamati sebagai sumber data.

Teknik analisis data yang digunakan dalam penelitian ini adalah analisis kualitatif yang digunakan peneliti sebagaimana yang dikemukakan Miles dan Hubberman (Sugiyono, 2007) yaitu pengumpulan data, reduksi data, penyajian data dan langkah terakhir adalah penarikan kesimpulan.

\section{HASIL DAN PEMBAHASAN}

\section{Blended Librarian di Perguruan Tinggi}

Peran blended librarian di lingkungan perguruan tinggi sangat diperlukan dalam mendukung Tri Dharma Perguruan Tinggi dimana pustakawan turut memfasilitasi proses pendidikan, penelitian dan pengabdian kepada masyarakat serta berperan dalam meningkatkan atmosfer akademik. Semakin berkembangnya teknologi informasi di era digital, pustakawan dituntut untuk dapat memahami dan menguasai aplikasi ataupun media pembelajaran yang behubungan dengan kurikulum, pendidikan, maupun penelitian . (Naibaho, 2018) dalam penelitiannya menyatakan bahwa pustakawan dapat menjadi mitra bagi sivitas akademika dalam menyelesaikan tugas-tugas akademik, mengembangkan riset, menyelesaikan publikasi ilmiah, meningkatkan literasi, dan menyediakan lingkungan pembelajaran yang kondusif.

Melihat semakin besar tuntutan akademik bagi mahasiswa, membuat pustakawan semakin harus mengupgrade kemampuannya sesuai dengan keadaan kurikulum di perguruan tinggi. (Nielsen, 2013) dalam penelitian menyatakan bahwa blended librarian perlu memperluas pengetahuan dan keterampilan yang dimiliki berkaitan dengan teknologi, penggunaan e-journal dan e-book, pengelolaan media sosial untuk kolaborasi dan komunikasi, pengetahuan tentang pembuatan materi audiovisual. Di samping itu blended librarian perlu memiliki pemahaman dan keterampilan untuk desain manajemen informasi dan sistem temu balik informasi elektronik dan tercetak.

\section{Implementasi Blended Librarian di UMY}

Jenis informasi dan tools pendukung akademik yang semakin berkembang sangat dibutuhkan oleh mahasiswa dan dosen, baik untuk keperluan pembelajaran maupun penelitian. Hal tersebut membuat pustakawan atau blended librarian harus mampu beradaptasi dan menyesuaikan diri dengan tantangan akademik dalam menguasai semua yang dibutuhkan oleh mahasiswa dan dosen. Berdasarkan hasil observasi peneliti peran blended librarian di Perpustakaan UMY sangat berperan penting dalam menjadi media atau bahkan instruktur guna membantu mahasiswa maupun dosen dalam proses menunjang kebutuhan akademik.

Dalam penelitian ini ditemukan beberapa implementasi konsep blended librarian di UMY. Penerapan blended librarian ini dibagi dalam beberapa point, sebagai berikut:

1. Manager

a. Menyediakan dan Mengelola Sumber Referensi

Perpustakaan UMY menyediakan berbagai jenis bahan pustaka baik dalam bentuk cetak maupun non-cetak (digital). Adapun bahan pustaka yang dimiliki oleh Perpustakaan UMY antara lain seperti buku, skripsi, jurnal, prosiding, majalah, dan koran. Selain itu, pustakawan juga 
menyediakan akses basis data e-resources, yang telah dilanggan oleh Universitas Muhammadiyah Yogyakarta.

Salah seorang pustakawan, NDF menjelaskan bahwa Universitas Yogyakarta Muhammadiyah melanggan beberapa database e-jurnal, yaitu JTOR, ProQuest, Emerald, dan EBSCO. Untuk mengoptimalkan akses database tersebut, pustakawan mensosialisasikan database e-jurnal kepada mahasiswa melalui media sosial, kelas literasi informasi, dan kelas user education.

b. Menyediakan Fasilitas dalam Mendukung Learning Commons

Selain menyediakan koleksi perpustakaan, perpustakaan UMY juga menyediakan layanan corner, yaitu American Corner, Warung Prancis, dan Muhammadiyah Corner. American Corner adalah kemitraan antara humas Kedutaan Besar Amerika Serikat di Indonesia dengan Universitas Muhammadiyah Yogyakarta. American Corner secara resmi dibuka pada tanggal 25 April 2004. Selain menyediakan koleksi di media cetak dan multimedia, American Corner dan Warung Perancis rutin mengadakan acara yang diadakan di dalam dan di luar setiap sudut. Di setiap acara selalu melibatkan sukarelawan di setiap corner tersebut, seperti melibarkan mahasiswa dan masyarakat. Siswa juga dapat belajar tentang budaya dan bahasa asing dengan mahasiswa asli dari negara asalnya yang sedang menempuh pendidika di Indonesia. Melalui program ini, mereka bisa mendapatkan pengetahuan yang lebih luas melalui American Corner dan Warung Perancis.

Mahasiswa dapat mencari dan membaca buku referensi tentang sejarah dan pengetahuan Kemuhammadiyahan di Muhammadiyah Corner. Tidak hanya menyediakan koleksi Kemuhammadiyahan, tetapi pustakawan juga mengadakan agenda rutin seperti bedah buku dan menonton film bersama tentang tokoh-tokoh Muhammadiyah.

c. Optimalisasi Ruang Komputer untuk Akses Informasi

Pustakawan bekerja sama dengan Biro Sistem Informasi UMY untuk mengembangkan sistem informasi dan teknologi komputer di Perpustakaan UMY. Hal ini bertujuan untuk memenuhi kebutuhan informasi mahasiswa di era digital. Untuk menambah ilmu pengetahuan di era digital, Perpustakaan UMY juga menyediakan Ruang Komputer yang terletak di lantai tiga Perpustakaan UMY yang dapat digunakan oleh semua civitas akademika secara gratis. Salah satu pustakawan, EK menjelaskan bahwa selama ini ruang komputer sering digunakan oleh mahasiswa UMY untuk berbagai keperluan. Ada beberapa mahasiswa yang menggunakan ruang komputer untuk mengerjakan tugas, mencari referensi, mengisi waktu luang, hingga menggunakannya untuk bersenang-senang. Sehingga, diharapkan di era digital saat ini, mahasiswa akan terus memanfaatkan fasilitas perpustakaan secara lebih optimal.

2. Mediator

a. Sebagai Penghubung dengan Sumber Referensi di Luar Universitas

Dalam rangka memenuhi kebutuhan referensi mahasiswa, Perpustakaan UMY bergabung dalam Jogja Library for All (JLA), yang merupakan jaringan perpustakaan di Daerah Istimewa Yogyakarta untuk menyediakan akses informasi tentang koleksi perpustakaan secara online bagi mahasiswa. Sehingga, pustakawan dapat menjadi mediator untuk menghubungkan mahasiswa UMY untuk mencari referensi lain di seluruh perguruan tinggi di Yogyakarta. Syarat untuk menjadi anggota JLA yaitu mahasiswa dapat mengisi formulir online melalui http://www.jogjalib.com. Setelah itu PIC di setiap perpustakaan pendaftaran asal akan memberikan konfirmasi kepada mahasiswa tersebut.

LN mengatakan bahwa saat ini implementasi JLA, UMY bekerja sama dengan UGM dan BPAD untuk mengadakan silang pinjam. Oleh karena itu mahasiswa yang sudah menjadi anggota JLA dapat meminjam buku di Perpustakaan UGM melalui sistem JLA.

b. Perantara Antara Fakultas dan Penerbit 
Universitas Muhammadiyah Yogyakarta memiliki Perpustakaan Pusat UMY dan perpustakaan fakultas yang berlokasi di setiap fakultas di UMY. Untuk pengadaan buku di perpustakaan fakultas, perpustakaan menawarkan kepada pihak fakultas untuk memberikan judul buku yang dibutuhkan oleh dosen untuk mendukung bahan ajar mereka. APW menjelaskan bahwa perpustakaan akan menerima judul yang diusulkan dari masing-masing fakultas. Setelah itu, pustakawan akan menghubungi penerbit buku untuk memesan buku usulan tersebut. Setelah buku-buku tersebut sampai di Perpustakaan UMY, buku-buku tersebut akan didistribusikan ke semua fakultas yang mengajukan buku tersebut.

3. Instruktur

\section{a. User Education}

User education adalah sosialisasi atau pelatihan untuk memberikan informasi tentang cara menggunakan fasilitas dan mendapatkan informasi di Perpustakaan UMY kepada mahasiswa, terutama mahasiswa baru. Pada kelas tersebut, pustakawan akan menjelaskan tentang situs web perpustakaan sekaligus memperkenalkan setiap menu pada situs web perpustakaan yaitu www.library.umy.ac.id . Setelah itu, pustakawan menjelaskan tentang layanan dan fasilitas yang dapat digunakan oleh mahasiswa di Perpustakaan UMY. Hal ini dimaksudkan agar semua mahasiswa baru dapat menggunakan dan memaksimalkan penggunaan layanan, fasilitas, dan sumber daya di Perpustakaan UMY.

b. Literasi Informasi

Di era digital, informasi yang disajikan di internet sangat berlimpah. Namun, tidak semua informasi yang diperoleh dari internet adalah informasi yang kredibel dan valid. Pustakawan akademik harus memiliki kemampuan dalam menyaring, mengintegrasikan, dan menyajikan informasi yang sesuai dengan kebutuhan pengguna. Salah satu layanan yang disediakan oleh Perpustakaan UMY adalah layanan kelas literasi informasi.

Menurut American Library Association, literasi informasi adalah seperangkat kemampuan yang mengharuskan individu untuk "mengenali kapan informasi dibutuhkan dan memiliki kemampuan untuk menemukan, mengevaluasi, dan menggunakan informasi yang dibutuhkan secara efektif." (Association, 2020). Untuk menjadi melek informasi, maka, seseorang membutuhkan keterampilan yang tidak hanya dalam penelitian, tetapi dalam pemikiran kritis.

Beberapa materi yang diajarkan dalam kelas literasi informasi sebagai berikut:

1) Pencarian e-resources

Tidak hanya sebagai penyedia informasi dalam bentuk buku, pustakawan juga membantu mahasiswa untuk mencari sumber informasi elektronik seperti e-jurnal, e-book, dan referensi online lainnya melalui internet. Oleh karena itu, pustakawan memberikan materi tentang bagaimana mencari sumber informasi elektronik dengan benar dan tepat, serta sesuai dengan kebutuhan penelitian mereka melalui kelas literasi informasi.

Metode yang digunakan dalam literasi informasi adalah metode Big 6. Dalam menggunakan metode Big 6, pustakawan membantu mahasiswa dalam proses menemukan fokus penelitian mereka dengan membuat pemetaan pikiran terlebih dahulu. Selain itu, pustakawan membantu mereka untuk melakukan brainstorming semua sumber informasi pendukung yang mungkin akan digunakan. Setelah itu, pustakawan membantu mereka untuk mencari sumber informasi yang terkait dengan penelitian mahasiswa menggunakan teknik Operator Boolean. Operator Boolean adalah salah satu jenis data di Java untuk menentukan alur pemrograman. Dengan begitu, mahasiswa akan dibantu untuk menemukan judul penelitian dan mendapatkan referensi yang sesuai dengan judul penelitian dengan tepat dan efisien.

2) Teknik Penulisan Karya Tulis Ilmiah

Penulisan karya tulis ilmiah harus dibuat secara koheren dan sistematis sehingga diperlukan teknik dalam menyusun makalah penelitian secara tepat dan benar. Oleh karena itu peran 
pustakawan diperlukan untuk membantu mereka dalam menyusun karya ilmiah atau tugas akhir mereka, baik dalam hal kepenulisan dan format makalah penelitian atau skripsi.

Dalam kelas teknik penulisan karya tulis ini, pustakawan menjelaskan tentang cara mengutip artikel dengan benar. Setelah itu, pustakawan mengajarkan tentang cara membuat daftar isi, daftar tabel, daftar gambar, daftar pustaka secara otomatis, dan indeks. Selain itu mereka diajarkan untuk membuat nomor halaman dengan angka romawi dan angka Arab dalam sebuah file.

\section{3) Pencegahan Plagiasi}

Universitas Muhammadiyah Yogyakarta telah menetapkan batas maksimum untuk tingkat plagiarisme karya akhir mahasiswa adalah $20 \%$ dengan tingkat similarity $1 \%$. Oleh karena itu peran pustakawan dibutuhkan untuk mensosialisasikan aturan tersebut kepada mahasiswa dan menjelaskan bagaimana mencegah plagiarisme.

Dalam kelas pencegahan plagiarisme, pustakawan menjelaskan tentang cara kerja aplikasi plagiarisme yang bernama Turnitin. Selain pengenalan aplikasi Turnitin, mereka juga diajarkan tentang cara mencegah atau meminimalisir tingkat plagiarisme pada karya ilmiah mereka. Hal ini bertujuan untuk meningkatkan kualitas karya ilmiah mereka

4) Pelatihan References Manager

References manager atau manajer referensi adalah aplikasi untuk membuat kutipan otomatis dalam Microsoft Word. Ada beberapa manajer referensi yang sering digunakan oleh civitas akademik UMY, yaitu Mendeley, Zotero, dan EndNote. Salah satu pustakawan, MEC mengatakan bahwa kelas manajer referensi ini sangat membantu mahasiswa untuk membuat sitasi secara otomatis dan cepat. Tidak hanya untuk mahasiswa saja, tapi kelas ini juga terbuka untuk dosen. Tidak jarang dosen meminta bantuan pustakawan dalam mengelola sumber referensi untuk penelitian mereka menggunakan manajer referensi. Mereka menyadari bahwa dalam menggunakan manajer referensi diperlukan seorang pustakawan untuk dapat membantu mereka dalam mengumpulkan bahan referensi penelitian mereka ke dalam aplikasi.

Dalam kelas manajer referensi ini, pustakawan memberikan materi tentang cara penggunaan aplikasi manajer referensi. Dalam menggunakan manajer referensi ini, mereka dapat membuat kutipan secara otomatis dan mengelola database referensi mereka di aplikasi manajer referensi mereka.

5) Pendamping Penelitian Dosen

Setiap dosen diwajibkan untuk melakukan penelitian sehingga dalam menyusun makalah penelitian tersebut, dosen harus mengumpulkan berbagai data, termasuk referensi pendukung. Peran pustakawan diperlukan untuk mendampingi penelitian dosen. Tidak sedikit dosen UMY yang membutuhkan bantuan pustakawan dalam menyusun makalah penelitian mereka, contohnya adalah membantu untuk menemukan referensi e-jurnal yang berkaitan dengan topik penelitian, menggunakan manajer referensi hingga membuat slide powerpoint.

Salah satu dosen UMY bernama RA, mengatakan bahwa dalam menyusun makalah penelitian, perlu untuk mendapatkan referensi pendukung sesuai dengan makalah penelitian mereka. Menurutnya, peran pustakawan penting untuk membantu dosen dalam mengumpulkan data dan referensi pendukung. Tidak jarang dalam penelitiannya, beliau meminta bantuan pustakawan untuk mencari referensi sesuai dengan makalah penelitiannya. Hal ini muncul karena ada rasa kepercayaan pada pustakawan dalam membantu dosen untuk menemukan referensi yang kredibel dan sesuai dengan topik penelitian. Serta membantu dalam menggunakan manajer referensi dalam penyusunan penelitian. 


\section{SIMPULAN}

Berdasarkan pembahasan di atas peneliti menarik simpulan bahwa penerapan konsep blended librarian di Perpustakaan Universitas Muhammadiyah Yogyakarta menciptakan konsep akademis yang dapat mendukung kebutuhan kurikulum bagi mahasiswa di Universitas Muhammadiyah Yogyakarta. Hal tersebut membuat peran blended librarian di Perpustakaan UMY berperan penting untuk menjadi media atau bahkan instruktur guna membantu mahasiswa maupun dosen dalam proses menunjang kebutuhan akademik. Sehingga profesi pustakawan sudah bukan hanya melayani pinjam kembali buku, namun juga bisa menjadi instruktur maupun problem solver bagi mahasiswa yang kesulitan dalam mengerjakan tugas kuliah mereka. Selain itu, dalam blended librarian juga menjadi partner bagi para dosen akademik dalam membantu mereka menyusun penelitian.

Berdasarkan hasil penelitian di atas, dapat diketahui bahwa peran blended librarian sangat penting untuk diterapkan di era digital, sehingga profesi pustakawan tetap dianggap penting dan dibutuhkan oleh seluruh civitas akademika. Ada beberapa peran pustakawan campuran yang telah diterapkan di Universitas Muhammadiyah Yogyakarta, sebagai berikut: 1) Menyediakan dan mengelola sumber referensi; 2) Menyediakan fasilitas yang mendukung learning commons; 3) Mengoptimalkan TIK untuk akses informasi; 4) Sebagai penghubung ke sumber lain di luar universitas; 5) User Education; 6) Literasi Informasi; 7) Pencegahan Plagiarisme; 8) Pelatihan Manajer Referensi; dan 9) Pendamping Penelitian Dosen.

\section{DAFTAR PUSTAKA}

Almah, H. (2014). Urgensi Pendidikan Pemakai ( User Education ) Bagi Pemustaka Di Perpustakaan Perguruan Tinggi Agama Islam: Sebuah Konsep Penerapan. Jurnal Ilmu Perpustakaan \& Kearsipan Khizanah Al-Hikmah, 2, 80-89. http://journal.uinalauddin.ac.id/index.php/khizanah-al-hikmah/article/view/143

Andayani, U. (2018). Strategi Pengembangan Kompetensi Pustakawan Akademik Sebagai Blended Librarian Dalam Penyedia Layanan Perpustakaan di Era Keilmuan Digital. $A l$ Maktabah, $\quad 17, \quad$ 13-24. http://journal.uinjkt.ac.id/index.php/almaktabah/article/view/11061/5684

Association, A. L. (2020). Information Literacy. https://literacy.ala.org/information-literacy/

Bell, Steven J., J. S. (2004). The blended librarian librarians. College \& Research Libraries News, August, 372-375. https://crln.acrl.org/index.php/crlnews/article/view/7297/7297

de Lima, G. Â., Maculan, B. C. M. dos S., \& Borges, G. S. B. (2017). Blended librarians in academic libraries: A Brazilian Panorama. Revista General de Informacion $y$ Documentacion, 27(2), 471-486. https://doi.org/10.5209/RGID.58213

Fatmawati, E. (2010). The Art of Library: Ikatan Esai Bergizi tentang Seni Mengelola Perpustakaan. Universitas Diponegoro.

Istiana, P. (2017). Pustakawan Berkualitas Tinggi: Urgensi Perpustakaan Perguruan Tinggi sebagai "Fountain of Knowledge". JIPI: Jurnal Ilmu Perpustakaan \& Informasi, 2(1), 107 114. http://jurnal.uinsu.ac.id/index.php/jipi/article/view/924/723

Naibaho, K. (2018). Blended skill bagi Pustakawan Akademik dalam menghadapi era Revolusi Industri. Blended Skill Bagi Pustakawan Akademik Dalam Menghadapi Era Revolusi 
Industri, 17(1). http://medpel.journal.ipb.ac.id/index.php/jpi/article/view/27261/17429

Nielsen, J. M. (2013). The Blended Business Librarian: Technology Skills in Academic Business Librarian Job Advertisements. Journal of Business \& Finance Librarianship, 18, 37-41.

Putri, G. R. (2019). Implementasi Blended Librarianship di Learning Resource Center Sekolah Tinggi Manajemen. Al Maktabah, 4(2), 120-127. https://ejournal.iainbengkulu.ac.id/index.php/almaktabah/article/view/2517/2045

Sugiyono. (2007). Metode Penelitian Kuantitatif Kualitatif dan R\&D. Alfabeta.

Sulistyo-Basuki. (2006). Metode Penelitian. Wedatama Widya Sastra.

Vargas, G. A. T., Vanderkast, E. J. S., García, A. A. R., \& González, J. T. G. (2015). The Blended Librarian and the Disruptive Technological Innovation in the Digital World. OALib, 02(08), 1-9. https://doi.org/10.4236/oalib.1101764

Yin, R. K. (2011). Studi Kasus: Desain Dan Metode. Raja Grafindo Persada.

Yusuf, M. C. (2015). Learning commons: Konsep pengembangan perpustakaan perguruan tinggi menghadapi generasi digital. Pustakaloka, 7(1), 119-128. 